\title{
Comparative morphology and histochemistry of the uropygial gland of the endangered and endemic Hooded Grebe (Podiceps gallardoi, Podicipediformes)
}

\author{
María Cecilia Chiale $^{1}$ (D) | Julieta Carril ${ }^{1,2}$ ｜ Diego Montalti ${ }^{2,3}$ | \\ Claudio Gustavo Barbeito ${ }^{1,2}$
}

${ }^{1}$ Facultad de Ciencias Veterinarias, Laboratorio de Histología y Embriología Descriptiva, Experimental y Comparada, Universidad Nacional de La Plata, Buenos Aires, Argentina

${ }^{2}$ Consejo Nacional de Investigaciones Científicas y Técnicas (CONICET), Buenos Aires, Argentina

${ }^{3}$ Facultad de Ciencias Naturales y Museo, Sección Ornitología, Universidad Nacional de La Plata, Buenos Aires, Argentina

\section{Correspondence}

María Cecilia Chiale, Facultad de Ciencias Veterinarias, Laboratorio de Histología y Embriología Descriptiva, Experimental y Comparada, Universidad Nacional de La Plata, Avenida 60 y 118, 1904 La Plata, Buenos Aires, Argentina.

Email: ceciliachiale@gmail.com

\begin{abstract}
The Hooded Grebe is an endangered and endemic species of Podicipediformes of Argentina. Many aspects of this bird's biology are still unknown including the uropygial gland. This is the first morphological and histochemical description of the uropygial gland for this species in a comparative context. The uropygial gland of these birds had parallel arranged lobes with a kidney-like shape, a conical papilla and a feather tuft in a sub-terminal position. The lobes were composed of tubular adenomers with a straight course that lead to secondary chambers. The capsule and connective tissue around the adenomers had elastic fibres. It showed a positive reaction to AlcianBlue/Periodic Acid Schiff and several lectins indicating the presence of glycoconjugates. The uropygial gland of the Hooded Grebe shares morphological characteristics with other aquatic species (e.g. secondary chambers) and the presence of glycoconjugates might suggest protective functions against microbes as previously proposed. The sub-terminal position of the feather tuft is a unique characteristic of this species indicating that this position leaves the tuft in a dorsal location and could be involved in parent-chick recognition mediated by odour transmission. Further studies are needed to increase our knowledge on some behavioural aspects of this species related to the biochemical composition of the uropygial secretion.
\end{abstract}

\section{K E Y W O R D S}

Aves, glycoconjugates, histology, Podiceps gallardoi, preen gland

\section{1 | INTRODUCTION}

The Hooded Grebe (Podiceps gallardoi; Rumboll, 1974) is a member of the order Podicipediformes, a monophyletic group and sister clade of Phoenicopteriformes within Neoaves (Hackett et al., 2008). It is an endemic species of Argentina with a few records in Chile, classified as critically endangered by the IUCN and with an estimated population of only 650-800 mature individuals (BirdLife International, 2019). These birds were described recently by Rumboll in 1974, they are gregarious and inhabit basaltic lakes in arid Patagonian steppes at elevations of 5001,200 m (Beltrán et al., 1993) where they reproduce, and during winter, they migrate to the Atlantic coast (Imberti et al., 2004). It is a species with a low reproductive rate, being the only species of Podicipediformes with a maximum two-egg clutch. Hatching is asynchronous, and both parents usually take care of a single chick leaving the remaining egg unhatched (Nuechterlein \& Johnson, 1982). The semi-altricial chick leaves the nest after hatching and 
goes through a period of "back-brooding" on the back of one of the parents (Nuechterlein, 1988).

The Podicipediformes are a morphologically homogeneous order (it comprises 6 genera and 22 species) having specializations to aquatic locomotion and to foot-propelled diving that include: a widening of the body providing water's stability, several modifications of the hindlimbs' musculoskeletal system, lobed feet, dense plumage providing insulation and buoyancy, and a large uropygial gland (UG) for waterproofing the plumage (Raikow, 1985). Available information on the UG of Podicipediformes is scarce and comprised of some very general morphological and histological aspects of only a few species, none of them the Hooded Grebe (Jacob \& Ziswiler, 1982; Johnston, 1988).

The UG is a sebaceous compact organ (Jacob \& Ziswiler, 1982; Kolattukudy, 1981) present in most avian species. This gland generally has two lobes and a papilla in its caudal end where the external ducts are situated and these can be surrounded by a feather tuft (Jacob \& Ziswiler, 1982; Johnston, 1988). According to Johnston (1988), tuft feathers can be classified as Type I (described as "downy" feathers and the most common type) and Type II and IIa (semiplumes, the difference between these two is that the middle portion of the rachis of Type IIa has no barbs). In water birds, the feather tuft is generally larger than in terrestrial birds (Chiale \& Montalti, 2013; Jacob \& Ziswiler, 1982).

At the histological level, the UG is a holocrine organ surrounded by a capsule of dense connective tissue from which the intermedial septum and thin branches that surround the adenomers originate (Reynolds et al., 2017). Apart from collagen fibres, the capsule and the intermedial septum also have reticular and elastic fibres, while the connective tissue around the adenomers is principally formed by reticular fibres (Carril et al., 2019; Chiale et al., 2014; Chiale et al., 2015; Chiale et al., 2016; Chiale et al., 2019). The lobes have tubular or tubuloalveolar adenomers with a stratified epithelium formed of four different strata: basal or germinative intermediate, secretory and degenerative (Jacob \& Ziswiler, 1982; Lucas \& Stettenheim, 1972). This secretor system converges in secondary chambers and eventually in a primary storage chamber (Chiale et al., 2014; Chiale et al., 2016; Chiale et al., 2019; Jacob \& Ziswiler, 1982; Kozlu et al., 2011). Lucas and Stettenheim (1972) divided the adenomers in three zones depending on the epithelial height and lumen width: Zone I (outermost), Zone II (media) and Zone III (innermost). The papillae region is rich in dense connective tissue and presents blood vessels, nerves and Herbst corpuscules (Chiale et al., 2014; Chiale et al., 2015). Generally, there are two external ducts for many avian species but this number can vary (Jacob \& Ziswiler, 1982; Reynolds et al., 2017), and when a tuft is present, they can be surrounded by a circlet of feathers (Chiale et al., 2014; Johnston, 1988).

The uropygial gland secretion consists of a complex mixture of lipids (Jacob, 1976); however, there are a variety of glycoconjugates in different bird species (Bhattacharyya, 1972; Chiale et al., 2015; Chiale et al., 2016; Chiale et al., 2019; Kamiya et al., 1986; Montalti, Quiroga, Massone, Idiart, \& Salibian, 2001). The study of glycoconjugates present in the uropygial gland secretion has been expanded with lectin-histochemistry technique studies showing diverse reactions. Birds that feed on carrion (e.g. Chimango Caracara (Milvago chimango) and Southern Caracara (Caracara plancus) displayed a positive reaction to many lectins (Chiale et al., 2015; Chiale et al., 2016, respectively) while seed-eating birds such as the Eared Dove (Zenaida auriculata) (Chiale et al., 2019) and the Monk Parakeet (Myiopsitta monachus) (Carril et al., 2019) showed a positive reaction to only a few of the lectins performed, indicating a lower variety of glycoconjugates.

The UG secretion has many functions, some of these include: contributing to the water-repellent properties of feathers (Jacob \& Ziswiler, 1982), improving feather resistance to abrasion (Moreno-Rueda, 2011), acting as a cosmetic enhancing plumage coloration (Amat et al., 2011; MorenoRueda, 2016), adding colour to eggs (Soler et al., 2014), producing olfactory cues (Amo et al., 2012; Hirao et al., 2009; Whittaker et al., 2018), controlling plumage hygiene and defending against microorganisms (Czirjak et al., 2013; Galván et al., 2008; Møller et al., 2009; Shawkey et al., 2003; Soler et al., 2012).

The objective of this study was to describe the morphological and histochemical aspects of the UG for the Hooded Grebe. We also analysed several characteristics of this organ within Podicipediformes and other members of the clade Aves and related our results to the particular ecological characteristics of the Hooded Grebe. We aimed to increase knowledge about this critically endangered species.

\section{2 | MATERIALS AND METHODS}

The specimens used in this study $(n=4)$ were found recently dead (without apparent injures in their internal organs) at Laguna C199, Meseta La Siberia, Santa Cruz province, Argentina (49 $02^{\prime}$ S $\left.-71^{\circ} 44^{\prime} \mathrm{W}\right)$ during December 2014 March 2015. They were donated to the Ornithological Collection of the Museum of La Plata by the Proyecto Macá Tobiano (Aves Argentinas). The body mass (BM) of each bird was assessed by a spring balance (accuracy $\pm 5 \mathrm{~g}$ ), and then, the UG was dissected in situ following the protocol in Montalti, Gutierrez, \& Salibián, (1998). Gland mass (GM) was measured with an accurate scale to the nearest $0.001 \mathrm{~g}$. After the measurements, the glands were preserved in $10 \%$ 
formalin. These values were used to calculate the relative gland mass $(\mathrm{RGM}=\mathrm{GM} / \mathrm{BM} \times 100)$.

The anatomical nomenclature used for the morphological descriptions follows Clark (1993). The lobes shape, cellular strata of the adenomers, lobules zones, external shape and orientation of the papilla and papilla type were classified according to Jacob and Ziswiler (1982). The tuft feathers' type was classified following Johnston (1988).

\subsection{Histological techniques}

Using standard histological techniques, transverse or parallel to the sagittal plane, cuts of the UGs were made and processed, including dehydration with increasing concentrations of alcohol, clearing with xylene, and infiltration and inclusion in paraffin. Samples were serially cut $(5 \mu \mathrm{m})$ and stained with haematoxylin-eosin for general histological description and stained with orcein to visualise elastic fibres and Gomori's trichromic to visualise collagen fibres (Survana et al., 2013).

\section{2 | Histochemical and lectin- histochemistry techniques}

Another set of samples was stained using the following histochemical techniques for the characterization of glycoconjugates (GCs): Periodic acid Schiff (PAS) to demonstrate GCs with oxidizable vicinal diols and/or glycogen, Alcian Blue $(\mathrm{AB})$ at different $\mathrm{pHs}$ were used to selectively identify the subtypes of acid mucins. GCs with carboxylic groups and $\mathrm{O}$-sulphated esters became evident with a $\mathrm{pH} 2.5$ solution, while sulpho-mucins and highly sulphated GCs were identified with $\mathrm{pH} 1.0$ and 0.5 solutions, respectively (Lev \& Spicer, 1964), and AB/PAS. This combined technique allows the identification of acid (AB positive), neutral (PAS positive) and mixed (AB/PAS positive) GCs in one section (Mowry, 1963)". Slices of Plains Viscacha (Lagostomus maximus) vagina previously positively recognized for these techniques (Flamini et al., 2012) were used as positive controls.

The lectin-histochemistry technique was performed following a standardized protocol frequently used in our laboratory (Chiale et al., 2015). Paraffin-included sections were deparaffinized, then incubated with $0.03 \% \mathrm{H}_{2} \mathrm{O}_{2}$ in methanol for $30 \mathrm{~min}$. to inhibit the endogenous peroxidase. After that, tissue slices were treated with $0.1 \%$ bovine serum albumin (BSA) in phosphate-buffered saline (PBS) for $30 \mathrm{~min}$, and incubated with biotinylated lectins (Table 1) for $2 \mathrm{hr}$ at room temperature. Slices were washed separately and incubated with the avidin-biotin-peroxidase complex (ABC) (Vector Laboratories, Burlingame, CA); diaminobenzidine (DAB) $0.02 \%$ (Biogenex, San Ramón, CA) was used as chromogen.

Staining intensity of both histochemical and lectin-histochemical techniques was graded according to a semiquantitative range: $(-)$ negative reaction, $(+)$ weak reaction, $(++)$ moderate reaction and $(+++)$ strong reaction.

Previously studied negative controls for lectin staining included: exposure to horseradish peroxidase and substrate
TABLE 1 Lectins used in the uropygial gland of the Hooded Grebe (Podiceps gallardoi) separated by groups according to their affinities and blocking sugars

\begin{tabular}{llll} 
Lectin & Acronym & Affinity & Blocking sugar \\
Group I & & & \\
$\begin{array}{l}\text { Concanavalia } \\
\text { ensiformis }\end{array}$ & CON-A & $\beta$-D-Man; $\alpha$-D-Man & D-methylmannose \\
$\begin{array}{l}\text { Group II } \\
\text { Triticum vulgaris }\end{array}$ & WGA & $\beta$-D-GlcNAc; NeuNac & $N$-acetylglucosamine \\
$\begin{array}{l}\text { Succinil Triticum } \\
\text { vulgaris }\end{array}$ & sWGA & $\beta 1,4$-D-GlcNac & $N$-acetylglucosamine \\
\hline $\begin{array}{l}\text { Lycopersicon } \\
\text { esculentum }\end{array}$ & LEA & $\beta 1,4$ GlcNac oligomers & $N$-acetylglucosamine \\
\hline $\begin{array}{l}\text { Group III } \\
\text { Glycine maximus }\end{array}$ & SBA & $\alpha$-D-GalNac; $\beta$-D-GalNac & $N$-acetylgalactosamine \\
\hline $\begin{array}{l}\text { Ricinus communis } \\
\text { Arachis hypogea }\end{array}$ & RCA-I & $\beta$-Gal & D-galactose \\
\hline $\begin{array}{l}\text { Griffonia } \\
\text { simplicifolia-I }\end{array}$ & GSA-I & $\beta$-Gal & D-galactose \\
\hline $\begin{array}{l}\text { Group IV } \\
\text { Ulex europaeus-I }\end{array}$ & UEA-I & L-Fuc & D-galactose \\
\hline
\end{tabular}

Abbreviations: Gal, galactose; GalNac, N-acetylgalactosamine; Glc, glucose; GlcNac, N-acetylglucosamine; L-Fuc, L-Fucose; Man, Manose; NeuNac, N-acetylneuraminic acid. 
medium without lectin, and blocking by incubation with the appropriate blocking sugars ( 0.1 to $0.2 \mathrm{M}$ in $\mathrm{PBS}$ ).

\section{RESULTS}

\section{1 | Morphology and histological description}

The UG (glandula uropygialis) of the Hooded Grebe was bilobed, and each lobe had a kidney-like shape (lobi glandulae uropygialis) and were separated at the base, joining together at the medial part of the gland, near the base of the papilla region (papilla uropygialis), giving the gland a parallel arranged external appearance (Figure 1). The papilla had a conical shape and the feather tuft (circulus uropygialis) comprised $12.5 \pm 1$ Type I feathers (Figure 1) which were inserted at the base of the papilla in a sub-terminal position. The direction of the papilla in relation to the plane of the lobes made a slightly obtuse angle (Figure 2). The RGM for this species was $0.285 \pm 0.07$.

The capsule of the UG (capsula uropygialis) of this species was thin and rich in collagen fibres. The interlobular septum (septum interlobare) was short and well-developed (Figure 3a). The branches of connective tissue surrounding the adenomers were very thin; however, this condition changes for the connective tissue surrounding the secondary chambers and became thicker. We also found elastic fibres as a component of the connective tissue of the capsule, interlobular septum and the connective tissue around the adenomers (Figure $3 b$ ).

The adenomers (secretory unities) were tubular, branched and with a straight course at the periphery of the gland. The

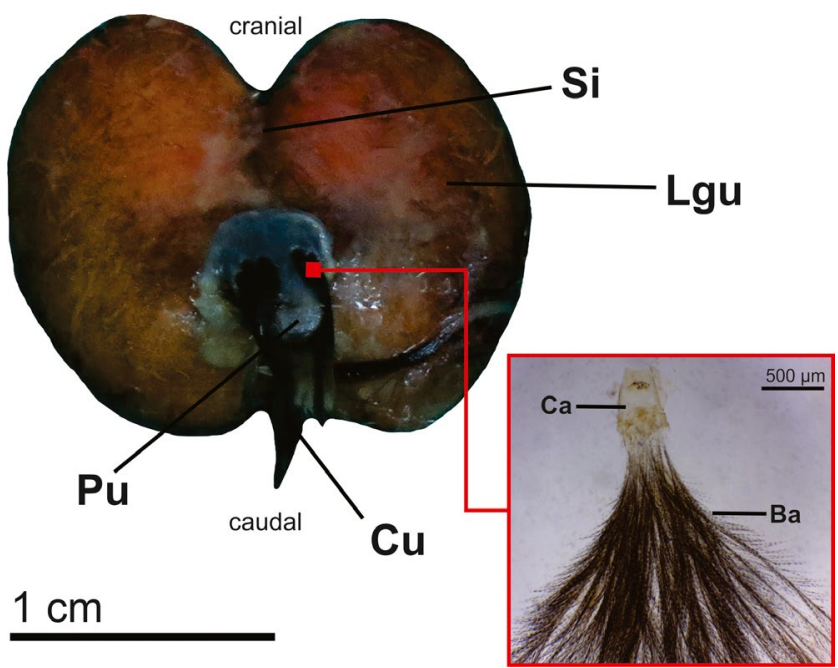

FIGURE 1 Macroscopic view of the UG of the Hooded Grebe (Podiceps gallardoi) showing a detail of a tuft feather. Abbreviations: ba, barbs; ca, calamus; cu, circulus uropygialis; lgu, lobus glandulae uropygialis; pu, papilla uropygialis; si, septum interlobare lobes could be divided in three zones: Zone I was composed of adenomers with 1 layer of basal or germinative stratum, 1-2 layers of intermediate stratum, 3-4 layers of secretory cells and 1-2 layers of degenerative stratum. Zone II adenomers had 1 layer of basal stratum, 1 layer of intermediate cells, 2-3 layers of secretory stratum and 1-2 degenerative layers, while Zone III adenomers were characterized of 1 layer of basal cells, 1 intermediate layer, 2 layer of secretory stratum and 1 layer of degenerative cells. The secondary chambers following the later adenomers had a stratified epithelium with no secretory characteristics (Figure 3c). The lumen widened towards these chambers. There was no evidence of a primary storage chamber.

The papilla was of delicate type, and it had abundant dense connective tissue formed of collagen and elastic fibres, blood vessels and two external ducts (one per lobe) lined with a cornified stratified epithelium with no secretory cells (Figure 3d). A distinctive feature of the papilla of this species was that the feather follicles were not surrounding the external ducts; these were placed in a sub-terminal position, near the transition zone between the lobes and the papilla (Figure 1).

\section{2 | Histochemistry and lectin- histochemistry}

Tables 2 and 3 summarize the histochemical and lectin-histochemistry results, respectively. Basal cells showed PAS and $\mathrm{AB}$ at different $\mathrm{pHs}$ positivity, the secretion had a moderate reaction to PAS and a weak reaction to $\mathrm{AB} \mathrm{pH} 2.5$ (Figure 4a), indicating the presence of glycogen or glycoconjugates with

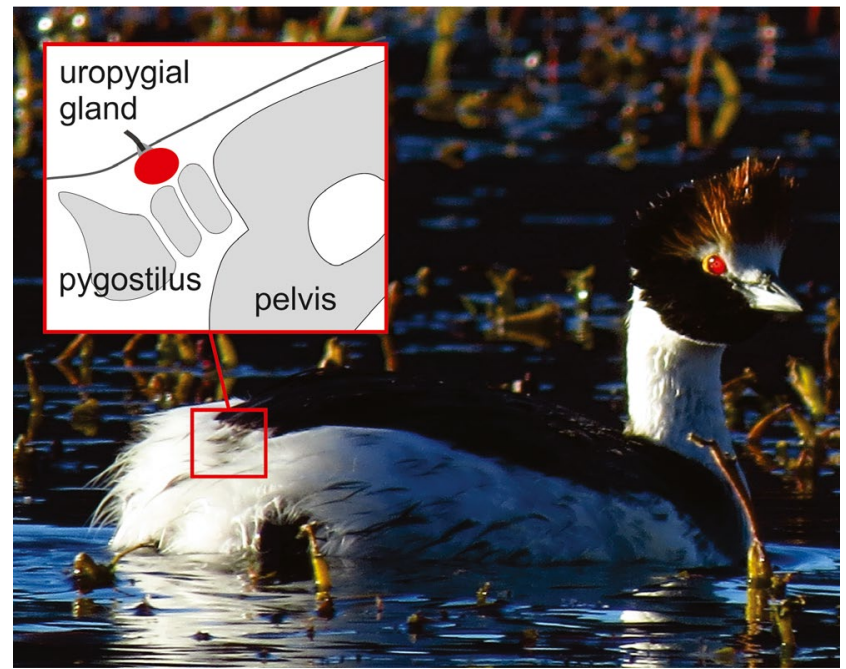

FIGURE 2 Anatomical representation of the position of UG of the Hooded Grebe (Podiceps gallardoi), the direction of the papilla and projection of the feather tuft from a lateral view. The photograph was taken by María Cecilia Chiale at Laguna C199, Meseta La Siberia, Santa Cruz, Argentina. 20 January 2015 
F I G URE 3 Uropygial gland of the Hooded Grebe (Podiceps gallardoi). (a) Coronal section stained with Gomori's trichrome (4X); (b) Coronal section stained with orcein (10X), the arrow shows elastic fibres in the connective tissue surrounding the adenomers; (c) Coronal section stained with Gomori's trichrome (4X) showing the secondary chambers; (d) Transversal section of the papilla stained with haematoxylineosin (4X). Abbreviations: cgu, capsule glandulae uropygialis; lgu, lobus glandulae uropygialis; 1, lumen; pd, porus ductus uropygialis; sc, secondary chamber; si, septum interlobare

TABLE 2 Histochemical techniques performed to the uropygial gland of the Hooded Grebe

T A B L E 3 Lectin binding pattern in different zones of an adenomer of the uropygial gland of the Hooded Grebe
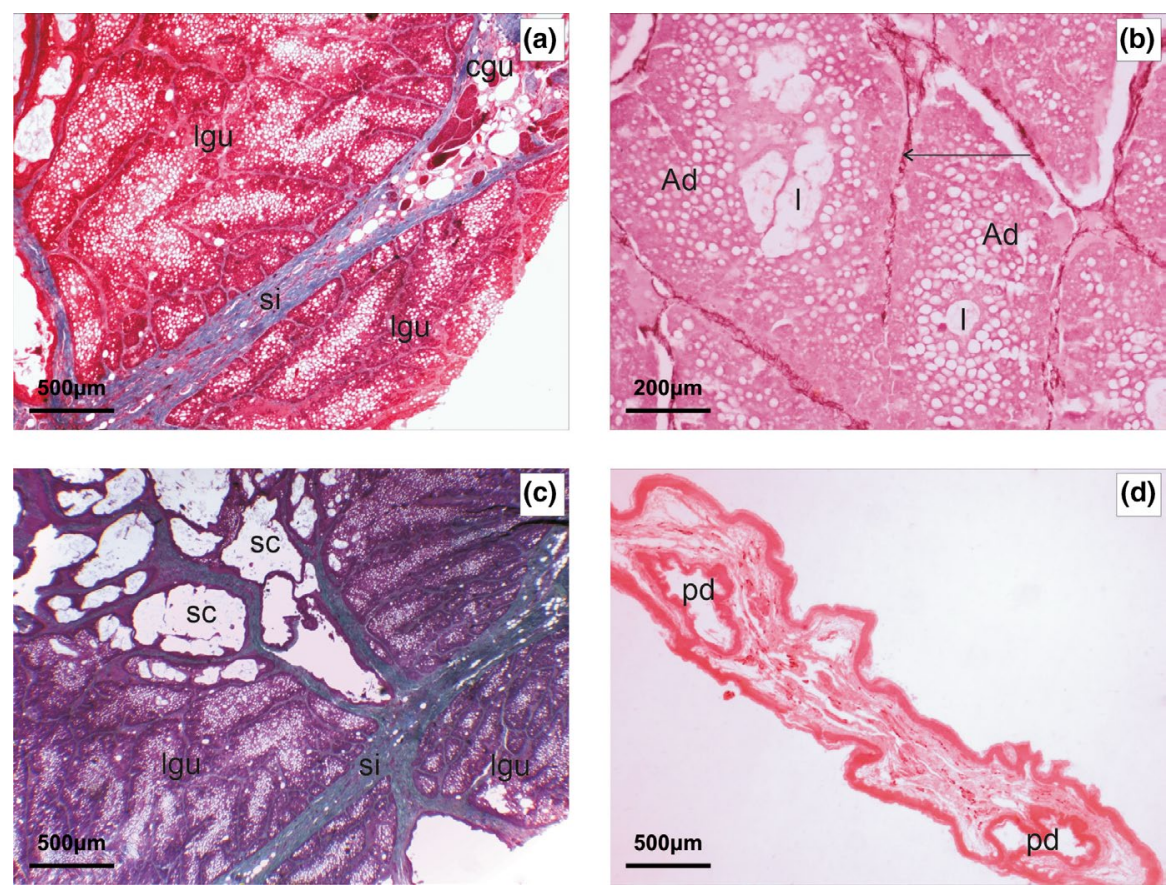

\begin{tabular}{lllll} 
Technique & $\begin{array}{l}\text { Basal } \\
\text { cells }\end{array}$ & $\begin{array}{l}\text { Intermediate and } \\
\text { secretory cells }\end{array}$ & Degenerative cells & Secretion \\
\hline PAS & ++ & - & + & + \\
\hline AB 0.5 & - & - & - & - \\
\hline AB 1 & - & - & - & - \\
\hline AB 2.5 & + & - & + & + \\
\hline AB/PAS & ++ & - & ++ & ++ \\
\hline
\end{tabular}

Note: -Negative reaction, + weak reaction, ++ moderate reaction.

\begin{tabular}{lllll} 
& Germinative & Intermediate and & $\begin{array}{l}\text { Degenerative } \\
\text { stratum }\end{array}$ & Secretion \\
Lectin & stratum & - & - & - \\
CON-A & - & - & - & - \\
LCA & - & + & + & + \\
WGA & + & - & - & - \\
SWGA & - & - & - & - \\
LEA & - & - & +++ & ++ \\
SBA & - & +++ & ++ & ++ \\
PNA & +++ & ++ & - & - \\
RCA-I & ++ & - & ++ & ++ \\
\hline GSA-I & - & ++ & + & + \\
\hline UEA-I & ++ & & + & + \\
\hline
\end{tabular}

Note: - Negative reaction, + weak reaction, ++ moderate reaction, +++ strong reaction. oxidizable vicinal diols and GCs with carboxyl groups or sulphated esters.

Regarding the lectin binding pattern, the UG of the hooded grebe showed positivity to several lectins performed. LCA lectin only reacted with the connective tissue, and no positive reaction to this lectin was found in the adenomers. Other lectins displayed a strong or moderate reaction along the adenomers and secretion (Figure $4 b-d$ ) which indicates the presence of carbohydrate residues such as $\beta$-Galactose, $\alpha$-Fucose and $\beta$-D- $N$-acetylglucosamine. 

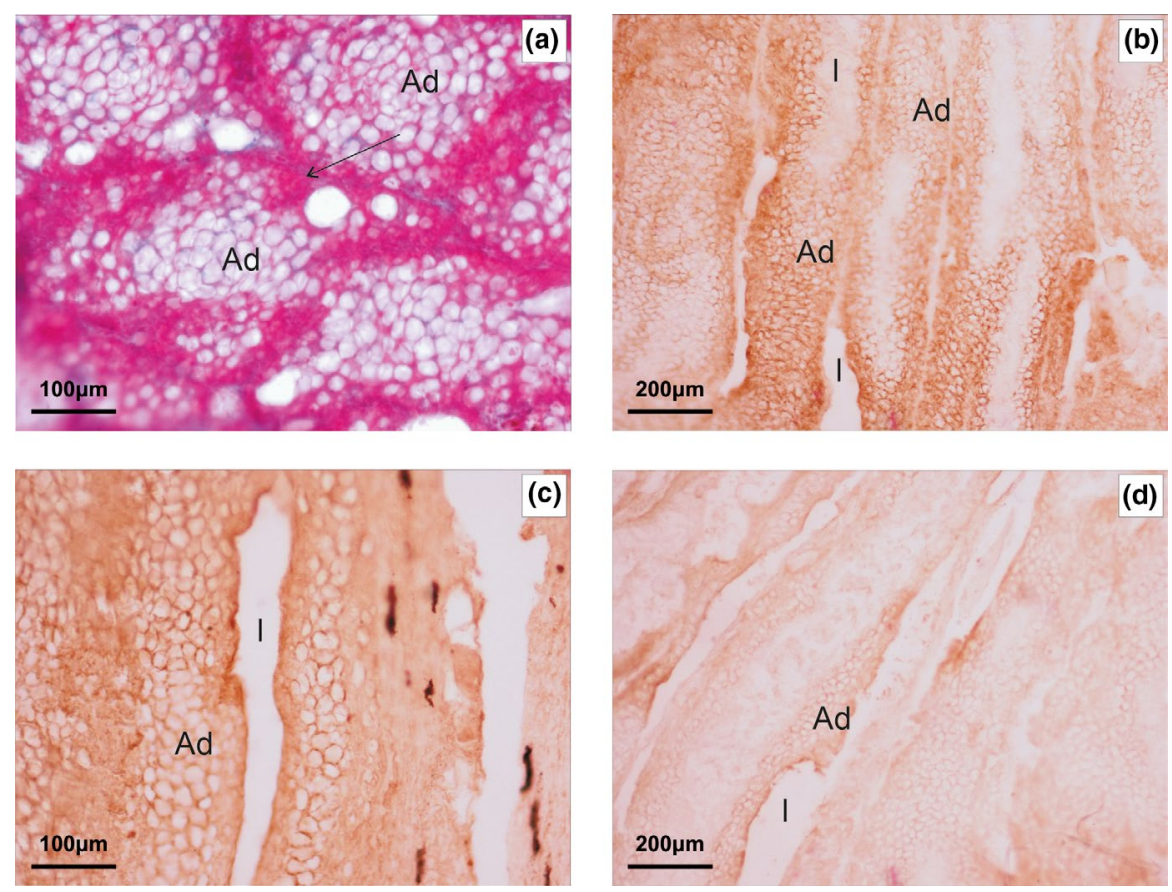

F I G URE 4 Histochemical and lectinhistochemistry of the UG of the Hooded Grebe (Podiceps gallardoi). A: AB/PAS 20X; B: PNA 10X; C: RCA-I 20X; D: WGA 10X. Abbreviations: Ad, adenomer; 1, lumen

\section{4 | DISCUSSION}

\section{1 | Comparative morphology of the UG of the Hooded Grebe within Podicipediformes and other bird species}

Our study is the first in depth morphological and histological description of the UG of the Hooded Grebe, an endemic and endangered bird species of Argentina discovered and described in the 1970s. The information presented in this study is very valuable because of the difficulty to obtain well-preserved samples of this critically endangered species. It is well known that the UG varies in shape and size among species and sometimes among closely related ones (e.g. in Psittaciformes, Carril et al., 2019). When comparing our results with the information available for other Podicipediformes, the UG of the Hooded Grebe is very similar to that of other grebe species (Jacob \& Ziswiler, 1982; Johnston, 1988). The parallel arranged external appearance of the lobes, the conical papilla and the Type I tuft feathers of the Hooded Grebe are characters common to all Podicipediformes and shared with some species of other orders (e.g. conical papilla: Accipitriformes, Falconiformes and Columbiformes; Type I feathers: most orders of birds). However, the kidney-like shape of the UG is an exclusive feature of Podicipediformes.

There are few contradictory comments regarding the position of the tuft feathers in this group. Jacob and Ziswiler (1982) only analysed two species (Tachybaptus ruficollis and Podiceps cristatus) and registered between 14 and 18 tuft feathers without mentioning the position of the tuft while Johnston (1988), who included a larger number of species, noticed a terminal position of the feathers but mentioned that the former authors suggested a sub-terminal position for the species they had analysed. A novel characteristic of the hooded grebe is that the feather tuft position is sub-terminal and not terminal as proposed for the rest of the species. This sub-terminal location in the UG gives the feather tuft a more dorsal position in the birds' body (Figure 2), and it could be an adaptive trait linked to olfactory signals produced by the uropygial secretions and the characteristic back-brooding of the chicks in Podicipediformes (Ferguson, 1977; Nuechterlein, 1988). This behaviour starts right after hatching, lasts for 2-3 weeks and allows parents to feed their chicks and protect them from cold temperatures and predators (Vlug, 2002). It is known that the feather tuft of the UG is always saturated with secretions (Schumacher, 1919). Moreover, Galván and Møller (2013) postulated that the feather tuft plays a role in trapping secretions and odours produced by the UG. The sub-terminal position of the tuft in the Hooded Grebe might suggest involvement in parental-chick recognition mediated by the perception of odour. Future studies could focus on the composition of the uropygial secretion in this species and search for volatile compounds involved in odour transmission. It is well known that some ground-nesting shorebirds switch from monoester waxes (more volatile) to diester waxes (less volatile) during incubation and that these compounds are more difficult to detect by mammalian predators (Reneerkens et al., 2005). Since the hooded grebe is an aquatic species and builds its nests in the water using the stems of milfoil (Myriophyllum elatinoides), it might be feasible that monoesters predominate in the UG secretion of this species because they do not face the risk of predation by terrestrial mammals. However, one of the threats 
that the Hooded Grebe faces is predation by the American Mink (Neovison vison) (Roesler et al., 2012), and it would be interesting to evaluate whether this semiaquatic carnivore uses olfactory cues to prey over the Hooded Grebe.

The RGM of the Hooded Grebe is similar to that of other members of the order, and it corresponds to those values reported for birds that dive, swim or rest in water (Johnston, 1988). All of these data reinforce the hypothesis stating that aquatic birds have larger UGs than terrestrial birds (Jacob \& Ziswiler, 1982; Johnston, 1988; Møller et al., 2009).

Regarding the general histological characteristics, we found that the UG of the Hooded Grebe has secondary chambers but no primary storage chamber. This feature seems to be related to an aquatic environment since many aquatic birds lack this storage chamber, and the absence might be associated with a more continuous flow of secretion (Chiale et al., 2014). Grebes are divers and are always in contact with water possibly leading to a continuous flow of uropygial secretion necessary to maintain feathers in good condition for water repellence as reported for other aquatic species such as penguins and skuas (Chiale et al., 2014). Another aspect of the UG of the Hooded Grebe is the presence of elastic fibres. Although some studies did not find these fibres as components of the connective tissue of this gland (Hou 1928), many others found them in terrestrial and aquatic species (Carril et al., 2019; Chiale et al., 2015; Chiale et al., 2016; Chiale et al., 2019; Jacob \& Ziswiler, 1982). The function of these fibres could be related to a change of volume in this organ. It has been reported that the size of the UG is dynamic (e.g. increasing in size from non-breeding to breeding season (Pap et al., 2010; Vincze et al., 2013), and increasing size with age (Urkiv et al., 2018). Even though these modifications might be due to changes in the indexes of cell proliferation and cell death that lead to tissue restructuring, this dynamism could be facilitated by the presence of elastic fibres.

\section{2 | Histochemical and lectin- histochemistry analyses: possible protective function?}

GCs have very important functions, among which signalling mechanisms related to cell proliferation, cell death and immune response stand out (Gabius, 2000). The histochemical and lectin-histochemistry analyses of the UG of the Hooded Grebe revealed the presence of a few carbohydrates as part of GCs (glycolipids and glycoproteins) identified by PAS technique and the presence of GCs with carboxyl groups and/or sulphated esters by $\mathrm{AB} 2.5$ reaction. Recent studies showed similar results for other bird species (Carril et al., 2019; Chiale et al., 2015, 2016, 2019;
Shaffian \& Mobini, 2014). It has been demonstrated that these GC varieties have protective functions against microorganisms in several fish species (Díaz et al., 2008; Esteban, 2012; Yashpal et al., 2014). In addition, the lectin binding pattern showed the presence of other carbohydrate residues present in this gland. In aquatic mammals, such as seals, saccharide residues are liberated in the skin surface and act as an antimicrobial mechanism because of their ability to inhibit the adherence of fungi or bacteria to the skin (Meyer et al., 2000). Antimicrobial properties of the carbohydrate residues of the UG have been proposed (Chiale et al., 2015, 2016). While the UG of the Hooded Grebe displayed less positive reactions to lectins compared with caracaras (Chiale et al., 2015, 2016), $\alpha$-Fucose (revealed by UEA-I), $\beta$-Galactose (detected by RCA-I and PNA) and $\mathrm{N}$-acetylglucosamine (by WGA binding) are present and have been proposed as antimicrobial substances (Yasui, Tsukise, Fukui, Kuwahara, \& Meyer, 2005), which could imply a protective function against microorganisms in this species as well.

\section{5 | CONCLUSION}

This study contributes to the scarce knowledge and information regarding the Hooded Grebe, and it is the first thorough investigation of the UG of any Podicipediformes. The UG of the Hooded Grebe shares general histological characteristics with other aquatic bird species. In addition, the histochemical and lectin-histochemistry findings confirmed the presence of a variety of GCs in the UG of this species that might be related to protective functions against microbes of the uropygial secretion. Another interesting point is the sub-terminal position of the tuft feathers being a novel characteristic for these birds. It will be interesting to corroborate the position of the tuft feathers in other species of this group. More studies regarding this aspect are needed in order to understand why this position is only present in Podicipediformes and not in other bird species and if this difference could be related to a more exposed tuft, thereby facilitating the transmission of odours promoting parentalchick recognition given that only Podicipediformes perform back-brooding of their hatchlings.

\section{ACKNOWLEDGEMENTS}

We are deeply thankful to Pamela Denmon for her help providing editorial assistance on this manuscript through the AFO Editorial Assistance program. We also thank Proyecto Macá Tobiano (Aves Argentinas) for donating the specimens used in this study to the Ornithological Collection of Museo de La Plata. We are also very thankful to the reviewers for their comments and suggestions that improved the final version of this manuscript. There is no conflict of interest. 


\section{ORCID}

María Cecilia Chiale (D) https://orcid. org/0000-0003-2642-4971

\section{REFERENCES}

Amat, J. A., Rendón, M. A., Garrido-Fernández, J., Garrido, A., Rendón-Martos, M., \& Pérez-Gálvez, A. (2011). Greater flamingos Phoenicopterus roseus use uropygial secretions as make-up. Behavioural Ecology and Sociobiology, 65, 665-673. https://doi. org/10.1007/s00265-010-1068-z

Amo, L., Avilés, J. M., Parejo, D., Peña, A., Rodríguez, J., \& Tomás, G. (2012). Sex recognition by odour and variation in the uropygial gland secretion in starlings. Journal of Animal Ecology, 81, 605613. https://doi.org/10.1111/j.1365-2656.2011.01940.x

Beltrán, J., Bertonatti, C., Johnson, A., Serret, A., \& Sutton, P. (1993). Actualizaciones sobre la distribución, biología y estado de conservación del macá tobiano (Podiceps gallardoi). Hornero, 13, 193-199.

Bhattacharyya, S. P. (1972). A comparative study on the histology and histochemistry of uropygial glands. Cellule, 69, 113-126.

BirdLife International (2019). Podiceps gallardoi. The IUCN Red List of Threatened Species 2019: e.T22696628A145837361.

Carril, J., Chiale, M. C., \& Barbeito, C. G. (2019). The uropygial gland of the monk parakeet Myiopsitta monachus: Histology, morphogenesis, and evolution within Psittaciformes. Evolution and Development, 22, 269-282. https://doi.org/10.1111/ede.12327

Chiale, M. C., Carril, J., Montalti, D., \& Barbeito, C. G. (2019). The uropygial gland of the Eared Dove and its evolutionary history within the Columbiformes (Aves). Journal of Ornithology, 160, 1171-1181. https://doi.org/10.1007/s10336-019-01691-6

Chiale, M. C., Fernández, P. E., Gimeno, E. J., Barbeito, C. G., \& Montalti, D. (2014). Morphology and histology of the uropygial gland in Antarctic birds: Relationship with their contact with the aquatic environment? Australian Journal of Zoology, 62, 157-165. https://doi.org/10.1071/ZO13103

Chiale, M. C., \& Montalti, D. (2013). The relationship between the feather tuft of the uropygial gland and terrestrial/aquatic birds. Revista Brasileira De Ornitologia, 21, 162-167.

Chiale, M. C., Montalti, D., Flamini, M. A., \& Barbeito, C. G. (2016). The uropygial gland of the Southern Caracara (Caracara plancus; Falconidae, Falconinae): Histological and histochemical aspects. Acta Zoologica, 98, 245-251. https://doi.org/10.1111/azo.12171

Chiale, M. C., Montalti, D., Flamini, M. A., Fernández, P. E., Gimeno, E. J., \& Barbeito, C. G. (2015). Histological and histochemical study of the uropygial gland of chimango caracara (Milvago chimango, Vielliot 1816). Biotechnic and Histochemistry, 91, 30-37. https:// doi.org/10.3109/10520295.2015.1068953

Clark, J. A. Jr (1993). Integumentum communae. In J. Baumel, A. King, J. Breazile, H. Evans, \& B. J. Vanden (Eds.), Handbook of avian anatomy: Nomina anatomica avium, Vol. 23 (pp. 17-44). Publications of the Nuttall Ornithological Club.

Czirják, G. Á., Pap, P. L., Vágási, C. I., Giraudeau, M., Mureşan, C., Mirleau, P., \& Heeb, P. (2013). Preen gland removal increases plumage bacterial load but not that of feather degrading bacteria. Naturwissenschaften, 100, 145-151. https://doi.org/10.1007/s0011 4-012-1005-2

Díaz, A. O., García, A. M., \& Goldemberg, A. L. (2008). Glycoconjugates in the mucosa of the digestive tract of Cynoscion guatupuca: A histochemical study. Acta Histochemica, 110, 76-85. https://doi. org/10.1016/j.acthis.2007.08.002
Esteban, M. A. (2012). An overview of the immunological defenses of fish skin. ISRN Immunology, 2012, 1-29. https://doi. org/10.5402/2012/853470

Ferguson, R. S. (1977). Adaptations of the Horned Grebe for breeding in prairie pothole marshes. M.S. thesis. University of Manitoba.

Flamini, M. A., Díaz, A. O., Barbeito, C. G., \& Portianski, E. L. (2012). Morphology, morphometry, histochemistry and lectin histochemistry of the vagina of the Plains Viscacha (Lagostomus maximus). Biotechnic and Histochemistry, 87, 81-94. https://doi. org/10.3109/10520295.2010.518497

Gabius, H. J. (2000). Biological information transfer beyond the genetic code: The sugar code. Naturwissenschaften, 87, 108-121. https:// doi.org/10.1007/s001140050687

Galván, I., Barbar, E., Piculo, R., Canto, J. L., Cortes, V., Monros, J. S., Atienzar, F., \& Proctor, H. (2008). Feather mites and birds: An interaction mediated by uropygial gland size? Journal of Evolutionary Biology, 21, 133-144. https://doi. org/10.1111/j.1420-9101.2007.01459.x

Galván, I., \& Møller, A. P. (2013). Odor transmission and olfaction: The tuft of the uropygial gland and olfactory ability in birds. Condor, 115, 693-699. https://doi.org/10.1525/cond.2013.120188

Hackett, S. J., Kimball, R. T., Reddy, S., Bowie, R. C. K., Braun, E. L., Braun, M. J., Chojnowski, J. L., Cox, W. A., Han, K.-L., Harshman, J., Huddleston, C. J., Marks, B. D., Miglia, K. J., Moore, W. S., Sheldon, F. H., Steadman, D. W., Witt, C. C., \& Yuri, T. (2008). A phylogenomic study of birds reveals their evolutionary history. Science, 320, 1763-1768. https://doi.org/10.1126/science.1157704

Hirao, A., Aoyama, M., \& Sugita, S. (2009). The role of uropygial gland in sexual behavior in domestic chicken Gallus gallus domesticus. Behavioural Processes, 80, 115-120. https://doi.org/10.1016/j. beproc.2008.10.006

Hou, H. C. (1928). Studies on the glandula uropygialis of birds. American Journal of Physiology, 85, 380.

Imberti, S., Sturzenbaum, S. M., \& McNamara, M. (2004). Actualización de la distribución invernal del Macá Tobiano (Podiceps gallardoi) y notas sobre su problemática de conservación. Hornero, 19, 83-89.

Jacob, J. (1976). Bird waxes. In P. E. Kolattukudy (Ed.), Chemistry and biochemistry of natural waxes (pp. 93-146). Elsevier.

Jacob, J., \& Ziswiler, V. (1982). The uropygial gland. In D. S. Farner, J. R. King, \& K. C. Parkes (Eds.), Avian biology, Vol. 6 (pp. 199-324). Academic Press.

Johnston, D. W. (1988). A morphological atlas of the avian uropygial gland. Bulletin of the British Museum (Natural History Zoology Series), 54, 199-259.

Kamiya, S., Izumisawa, Y., Tsukushi, M., Amasaki, H., \& Daigo, M. (1986). Histochemical studies on polysaccharides in the uropygial gland of ducks. Bulletin of Nippon Veterinary and Zootechnical College, 35, 1-7.

Kolattukudy, P. E. (1981). Avian uropygial (preen) gland. Methods in Enzymology, 72, 714-720.

Kozlu, T., Akaydin-Bozkurt, Y., \& Ates, S. (2011). A macroanatomical and histological study of the uropygial gland in the White Stork (Ciconia ciconia). International Journal of Morphology, 29, 723-726.

Lev, R., \& Spicer, S. S. (1964). Specific staining of sulphate groups with alcian blue at low pH. Journal of Histochemistry and Cytochemistry, 12, 309. https://doi.org/10.1177/12.4.309

Lucas, A. M., \& Stettenheim, P. R. (1972). Uropygial gland. In A. M. Lucas, \& P. R. Stettenheim (Eds.), Avian anatomy. Part II (pp. 
613-626). Agricultural handbook. Department of Agriculture, U.S. Government Printing Office.

Meyer, W., Bollhorn, M., \& Stede, M. (2000). Aspects of general antimicrobial properties of skin secretions in the common seal Phoca vitulina. Diseases of Aquatic Organisms, 41, 77-79. https://doi. org/10.3354/dao041077

Møller, A. P., Czirjak, G. A., \& Heeb, P. (2009). Feather microorganisms and uropygial antimicrobial defenses in a colonial passerine bird. Functional Ecology, 23, 1097-1102. https://doi. org/10.1111/j,1365-2435.2009.01594.x

Montalti, D., Gutierrez, A. M., \& Salibián, A. (1998). Técnica quirúrigica para la ablación de la glándula uropigia en la Paloma Casera Columba livia. Revista Brasileira de Biología, 58, 193-196.

Montalti, D., Quiroga, M. A., Massone, A. R., Idiart, J. R., \& Salibian, A. (2001). Histochemical and lectin-histochemical studies of the secretion from the uropygial gland of the rock dove Columba livia (Columbidae-Columbiformes). Brazilian Journal of Biological Sciences, 18, 35-39.

Moreno-Rueda, G. (2011). House sparrows Passer domesticus with larger uropygial glands show reduce feather wear. Ibis, 153, 195198. https://doi.org/10.1111/j.1474-919X.2010.01082.x

Moreno-Rueda, G. (2016). Uropygial gland and bib colouration in the house sparrow. PeerJ, 4, e2102. https://doi.org/10.7717/peerj.2102

Mowry, R. W. (1963). The special value of methods that color both acidic and vicinal hydroxyl groups in the histochemical study of mucins. With revised directions for the colloidal iron stain, the use of alcian blue G8X and their combinations with the peryiodic acid Schiff reaction. Annals of the New York Academy of Sciences, 106, 402-426.

Nuechterlein, G. L. (1988). Parent-young vocal communication in western grebes. Condor, 90, 632-636. https://doi.org/10.2307/1368352

Nuechterlein, G. L., \& Johnson, A. (1982). The downy Young of the hooded grebe. Living Bird, 19, 69-72.

Pap, P. L., Vágási, C. I., Osváth, G., Muresan, C., \& Barta, Z. (2010). Seasonality in the uropygial gland size and feather mite abundance in house sparrows Passer domesticus: Natural covariation and an experiment. Journal of Avian Biology, 41, 653-661. https://doi. org/10.1111/j.1600-048x.2010.05146.x

Raikow, R. J. (1985). Locomotor System. In A. S. King, \& J. Mc Lelland (Eds.), Form and function in birds, Vol. 3 (pp. 57-147). Academic Press.

Reneerkens, J., Piersma, T., \& Sinninghe-Damsté, J. S. (2005). Switch to diester preen waxes may reduce avian nest predation by mammalian predators using olfactory cues. Journal of Experimental Biology, 208, 4199-4202. https://doi.org/10.1242/jeb.01872

Reynolds, S. M., Castro, I., Alley, M. R., \& Cunningham, S. J. (2017). Apteryx spp. (Kiwi) possess an uropygial gland: Anatomy and pathology. European Journal of Anatomy, 21, 125-139.

Roesler, I., Imberti, S., Casañas, H., \& Volpe, N. (2012). A new threat for the globally endangered Hooded Grebe Podiceps gallardoi: the American mink (Neovison vison). Bird Conservation International, 22, 383-388.

Rumboll, M. A. E. (1974). Una nueva especie de macá (Podicipedidae). Comunicaciones Del Museo Argentino De Ciencias Naturales, 4, 33-35.
Schumacher, S. (1919). Der Bürzeldocht. Annals of Anatomy, 52, 291-301.

Shaffian, A. H., \& Mobini, B. (2014). Histological and histochemical study on the uropygial gland of the goose (Anser anser). Bulletin Journal of Veterinary Medicine, 17, 1-8.

Shawkey, M. D., Pillai, S. R., \& Hill, G. E. (2003). Chemical warfare? Effects of uropygial oil in feather degrading bacteria. Journal of Avian Biology, 34, 345-349. https://doi. org/10.1111/j.0908-8857.2003.03193.x

Soler, J. J., Martín-Vivaldi, M., Peralta-Sánchez, J. M., Arco, L., \& Juárez-García-Pelayo, N. (2014). Hoopoes color their eggs with antimicrobial uropygial secretions. Naturwissenschaften, 101, 697705. https://doi.org/10.1007/s00114-014-1201-3

Soler, J. J., Peralta-Sánchez, J. M., Martín-Platero, A. M., MartínVivaldi, M., Martínez-Bueno, M., \& Møller, A. P. (2012). The evolution of size of the uropygial gland: Mutualistic feather mites and uropygial secretion reduce bacterial loads of eggshells and hatching failure of European birds. Journal of Evolutionary Biology, 25, 1179-1191. https://doi.org/10.1111/j.1420-9101.2012.02561.x

Survana, K., Layton, C., \& Bancroft, J. D. (2013). Bancroft's theory and practice of histological techniques. Elsevier.

Urkiv, J., Rattiste, K., Hõrak, P., Meitern, R., \& Sepp, T. (2018). Uropygial gland size: A marker of phenotypic quality that shows no senescence in a long-lived seabird. Biogerontology, 20(2), 141-148. https://doi.org/10.1007/s10522-018-9782-4

Vincze, O., Vágási, C. I., Kovács, I., Galván, I., \& Pap, P. L. (2013). Sources of variation in uropygial gland size in European birds. Biological Journal of the Linnaean Society, 110, 543-563. https:// doi.org/10.1111/bij.12139

Vlug, J. J. (2002). Red-necked Grebe. BWP Update, 139, 139-179.

Whittaker, D. J., Rossval, K. A., Slowinski, S. P., Soini, H. A., Novotny, M. V., \& Ketterson, E. D. (2018). Songbird chemical signals reflect uropygial gland androgen sensitivity and predict aggression: Implications for the role of the periphery in chemosignaling. Journal of Comparative Physiology A, 204, 5-15. https://doi.org/10.1007/ s00359-017-1221-5

Yashpal, M., Kumari, U., Mittal, S., \& Mittal, A. K. (2014). Glycoproteins in the buccal epithelium of a carp, Cirrhinus mrigala, (Pisces: Cyprinidae): A histochemical profile. Anatomia Histologia Embryologia, 43, 116-132. https://doi.org/10.1111/ahe.12055

Yasui, T., Tsukise, A., Fukui, K., Kuwahara, Y., \& Meyer, W. (2005). Aspects of glycoconjugates production and lysozyme and defensins expression of the ceruminous glands of the horse (Equus przewalskii f. dom.). European Journal of Morphology, 42, 127-134. https:// doi.org/10.1080/09243860500202507

How to cite this article: Chiale MC, Carril J, Montalti D, Barbeito CG. Comparative morphology and histochemistry of the uropygial gland of the endangered and endemic Hooded Grebe (Podiceps gallardoi, Podicipediformes). Acta Zool 2020;00:1-9. https://doi.org/10.1111/azo.12357 